\title{
Remarks on the migration crisis as a challenge to the European Union in the twenty-first century
}

Among the many crises tormenting the Old Continent, the course and consequences of the migration crisis that began in fall 2015 are particularly noteworthy. This crisis poses a serious challenge to the contemporary international order, especially in the European Union countries. There are four aspects that should be highlighted from a European perspective.

1. The migration crisis manifests the internal weakness of the EU, since neither EU structures nor individual countries have been able to predict, effectively neutralize and manage it properly in order to smooth its course and consequences. The outcome of the crisis is a weakening of the EU, manifested, among other things, in the impediment of integration processes and of Project Europe itself, which had already been undermined by the 2008 economic crisis, particularly in Greece; the conflict between Ukraine and Russia; and numerous terrorist attacks in many EU countries.

Piotr Buras, the Director of the Warsaw Office of the European Council on Foreign Relations observes: "We can already see that a certain model of integration has been exhausted. This is the communitarian model in which the Commission makes proposals for the whole of the Union. This can be seen in the migration policy. Since the outbreak of the refugee crisis in 2014, all proposals of the Commission have fallen through. The Commission was irrelevant in this matter.

The communitarian model is being replaced by the coalition of the willing formed by EU member states. The defense initiative of France is operating, in principle, outside the structures of the European Union. Germany is discussing how to limit immigration with Italy, France and Spain, without the Commission's involvement; and someday this group will likely negotiate the new rules on the readmission of migrants or development aid with Africa. Cooperation between countries in Europe will be strengthened. No country can cope with migration or climate problems on its own. Yet this will neither involve cooperation within the entire EU, nor be confined to its borders.

[...] Had it not been for the eurozone crisis in Greece or Italy, the migration crisis would have taken a completely different form. But it hit the countries that had been seriously weakened. Yet it would be a mistake to talk about a crisis of the EU. The crisis pertains to nation-states and the model of current liberal democracies, which are swaying under the pressure of globalization, migration, climate change, as well as changes to the functioning of the media or the public sphere" (Buras, 2018, p. 13).

2. The migration crisis has produced a division inside the EU due to the lack of member states' agreement on migration and asylum policy. This has led to the division into 'Western' countries, which were ready to admit agreed quotas of migrants and 
refugees (e.g. Germany, the Netherlands and Scandinavian countries) and 'Eastern' countries that opposed these provisions (openly or quietly), e.g. Poland, Hungary and the Czech Republic. In the opinion of many West Europeans, these countries have symbolically been degraded from being Central European to Eastern European. It is often argued that both sides, namely Western and Eastern Europe, cherish different values. On the one side it is multiculturalism, universalism, globalism, human rights and market society, on the other one - strong cultural identity, attaching excessive importance to the past, and the increasing importance of the state.

Uwe Rada writes in the Barbarian East that 'East' is associated with such features as savagery, barbarism, backwardness, provinciality, unpredictability or, generally, 'evil.' These divisions will have long-term consequences (Sakson, 2016).

3. The migration crisis has also led to internal political and social crises in many EU countries.

The mass influx of immigrants has triggered discontent and rage in what are called 'host countries,' which, due to their geographical location and the course of the main migration routes, have been forced to admit the main migration wave; first and foremost - Greece and Italy.

This was confirmed at the Brussels EU summit in October 2018, where migration was one of the main topics. It was agreed that the common goal of the $\mathrm{EU}$ is to reduce illegal migration to zero. However, it was stated that the mandatory distribution of refugees, proposed at the peak of the migration crisis in 2016, did not stand a chance of implementation. Nevertheless, it was agreed to support 'preventive' measures, namely to streamline the deportation procedure and strengthen Frontex, that is the EU's border guard. During the summit, the Austrian concept of 'binding solidarity' in refugee crises was considered, which would oblige all EU countries to offer help, although they could choose its form (Bielecki, 2018, p. 6).

In transit countries, such as the Balkans, Hungary and Austria, the migration wave has aggravated anti-immigration rhetoric, resulting among other things, in the turn to the right in parliamentary elections in Hungary and Austria.

Also the host countries, mainly Germany and the Scandinavian countries, have witnessed a clear crisis in the context of migration policy. For three years, the position of Chancellor Angela Merkel had been so weak that in summer 2018 Germany was at risk of early parliamentary elections due to internal contradictions within the CDU/ CSU regarding the migration policy.

An important argument that convinced many UK residents to vote for Brexit was their fear of another wave of migrants coming to the island. Sweden was also about to 'swerve to the right,' which indicates what sentiments prevailed there, as in Denmark or the Netherlands.

In Central and Eastern European countries, such as Poland and the Czech Republic, which have not suffered from the migration crisis whatsoever, it has nevertheless sparked an anti-immigration hysteria, which fueled domestic political games, effectively antagonizing their societies.

4. The far-reaching outcomes of the migration crisis can be seen in the rise of populist and xenophobic attitudes and the collapse of the dominant neoliberal ideology of contemporary capitalism and globalism. 
Growing populist tendencies in the West and East of Europe are fueled by, among other things, the alleged danger of a 'flood of immigrants' that is to lead to a civilizational catastrophe, like the one that the white South African community supposedly experienced after the abolition of apartheid. This issue has already begun to live its own life. At present, it is no longer mainly about the immigrants themselves, 1.3 million of who came to Europe in 2015. This year was exceptional, especially due to the war in Syria. In the first half of 2018, only 42,000 undocumented immigrants came to Europe. Therefore, it is more about the political perception of the problem, not about numbers. However, this perception is often more important than the reality, which is particularly evident in politics.

On December 10, 2018, the United Nations adopted the Global Compact for Migration at a conference in Marrakech, Morocco. Its signatories represented about 150 countries. The compact consists of 54 points, which include, for example, increasing the access to and flexibility of regular migration and minimizing the adverse factors which lead to people leaving their country of origin. The document also discusses coordinated international activities regarding migrants who have gone missing, as well as strengthening the cross-border combat with migrant smuggling. Poland, Austria, the Czech Republic, Hungary and the United States have withdrawn from the compact that was negotiated and discussed for six months (Louven, 2018, p. 11).

The contemporary dimension of migration and multiculturalism is closely related to globalization, which is characterized by professional mobility. This has been an outcome of EU enlargement and the disappearance of its internal borders, as well as political, social, economic or religious crises in various parts of the world. They often lead to bloody internal conflicts, armed interventions and wars that bring about mass displacements and people fleeing to safe regions and countries.

Immigrants are often portrayed as a threat and source of anxiety and social problems. On this basis the project of a multicultural European society is criticized. Europeans associate terrorism and the threat of Islamization with potential immigrants from Africa and the Middle East. While these attitudes are not supported by any rational evidence, they build symbolic and mental barriers with different cultural and religious worlds. This is also seen in Poland. The results of research carried out by the Public Opinion Research Center (CBOS) in December 2017, show that 74 percent of Poles are against the relocation of refugees and immigrants in Poland, including 43 percent of respondents who are strongly against it. Just three years ago these proportions were inverse.

The issue of migration and multiculturalism is becoming one of the most important challenges of modern times, along with, for example, globalization, climate change, the social consequences of technological development and the reconstruction of the global order in its political and economic dimensions.

Twenty-five years after 1989, an ideological and political counterrevolution is taking place not only in Poland and Hungary. It ranges from Putin's Russia to Trump's America. In Western Europe, it takes the form of Brexit and has the face of Madame Le Pen, in Dresden - it is Pegida's 'Monday walks' (Krzemiński, 2018, pp. 66-68).

Populism has broken out in response to rapid social changes and the evolution of value systems. An 'invisible revolution' of identity has taken place. As Grzegorz 
Ekiert notes: "When the individualization of societies and the strengthening of values such as gender equality, multiculturalism, cosmopolitanism, and acceptance of sexual minorities progress rapidly and go far, people attached to traditional values organize themselves to fight them. Populism is a reaction to a change in values and customs. Support for Trump, Kaczyński, Orban, and Erdogan is mainly cultural, rather than class-related. They are supported by the less educated people from smaller towns, who are older, more religious, and identify with more traditional values.

Traditional institutions, models of life and careers are losing their meaning. When everything is changing, nobody feels confident, because it is unclear what the results of these changes can bring for them. Even the elites who feel the best in the new circumstances have failed to predict all the consequences of the expansion of freedom. Ordinary people have experienced the unpredictability of the effects of even the best changes to a larger extent. They have been living in anxiety for years. Many people feel that even if nothing is being taken away from them, they can lose something when everything is changing" (Jak straciliśmy..., 2018, pp. 27-31).

Anxiety is another reason for the populist shift, next to uncertainty. Cultural uncertainty has increased because of anxiety. When asked by CBOS: "Are you afraid that we will lose our culture as immigration increases?," 73 percent of Czechs answered "Yes," as well as 68 percent of Slovaks, 65 percent of Hungarians and 44 percent of Poles.

A quarter of a century of changes in Central and Eastern Europe, including in the former East Germany, has resulted in fatigue with structural changes. First, "we have built democracy and market economy. Then, we have adapted to advanced EU standards. This has involved a process of redesigning institutions, procedures and lives of people whose world had changed disturbingly" (Jak straciliśmy..., 2018, p. 28).

Conservative thinker Marek Cichocki notes that "the migration crisis has obviously inspired imagination and speculations about the fall of European civilization, although we have to realize that it is different from what happened in Europe in the twentieth century. However, the feeling of a new threat certainly brings basic identity questions back. What do we really want to save from our civilization? Can anything be saved at all? I believe that saving is necessary, but we must honestly answer the question of what we value, what we cannot live without, and what we have to take with us into the future to be who we are and who we want to be" (Cichocki, 2018, p. 5).

There are more and more questions about the future in the public space. They are inspired by various fears. These anxieties pertain to social issues, to whether the current model can be preserved, whether the EU will survive, whether there will be a war, or if refugees will flood us. The basic question is if we will be able to lead a peaceful life.

Populists - opponents of liberal democracy - believe that the world is a dangerous place. If you do not defend yourself against others, they will devour you. For this reason, refugees arouse extreme emotions, because they are different (in terms of culture, religion, skin color and place of origin). The migration crisis has strongly polarized European societies, leading to a significant evolution of social attitudes from acceptance and understanding to resentment and hostility. 
This has been manifested by growing hostility towards Muslims and numerous instances of aggression (verbal and physical) directed against 'aliens' - real or imaginary Muslims (the image of the 'global Muslim'). These sentiments are rooted in old and new prejudices and stereotypes.

A comparative study by the PEW Research Center in 2018 shows that Germany is in a group of countries that continue to support admitting refugees to the largest extent. According to this survey, 82 percent of Germans believe that European countries should admit people who come to Europe to flee from war and violence. Only 12 percent of German citizens are of the opposite opinion. Support for sheltering refugees is higher only in Spain (86 percent) and the Netherlands (83 percent). It is also high in Sweden (81 percent), France (79 percent), the United Kingdom (74 percent) and Greece (59 percent). According to this survey, 49 percent of Poles are in favor of admitting refugees, while 36 percent are against it.

The PEW Research Center also asked questions about how the EU was handling the refugee issue. In most of the countries surveyed, EU activities in this area are assessed negatively. The greatest discontent is seen in Greece, where 92 percent of citizens assess the EU critically. Sweden (84 percent), Hungary (80 percent), Italy (78 percent), France (74 percent) and Spain (71 percent) also demonstrate a high level of discontent. In Poland, 67 percent of citizens negatively assess EU refugee policy, and in Germany - 66 percent (Serwis, 2018, p. 1).

In light of this study, one might be surprised by the many modern manifestations of anti-Semitism and hostility towards immigrants in Germany, e.g. in Chemnitz in 2018, the attitude of the inhabitants of Brandenburg to the Schengen Area, or the antiMuslim and populist AfD party, which has become the third political force in Germany and the second largest in the former Eastern Germany.

In May 2018, the results were published of representative studies in Brandenburg, bordering Poland, on the subject of reintroducing border controls with Poland. According to studies of the Infratest Dimap Institute, 42 percent of the inhabitants of this German Land want to reinstate border controls with Poland. The highest percentage of supporters of closing the border was recorded among adherents of the AfD (68 percent), the lowest among followers of the Alliance 90/Greens (26 percent). Forty-three percent of CDU supporters were in favor of introducing permanent border controls (FDP - 39 percent, SPD - 32 percent, Die Linke - 28 percent). Closing the border with Poland was almost evenly supported across all age groups (16-44 years old -41 percent, 45-64 years old - 41 percent, over 65 years old -44 percent). Overall, 51 percent were against and 7 percent had no opinion. The authors of the study do not explain the reasons for this. ${ }^{1}$

The migration crisis also has moral and ethical dimensions. The discrepancies between the core values declared at the European level and their implementation in specific actions can be described as the 'non-strategic hypocrisy' of the EU. This can be exemplified by the violation of a basic value, namely the refugees' right to protection. In the past, Europeans saw immigrants as evidence that the European world was attractive. Today they see their own weakness and failure in immigrants.

${ }^{1}$ https://www.rbb24.de/politik/beitrag/2018/05/knapp-haelfte-brandenburger-wuenscht-qrenzkontrollen-polen.html, 10.05.2018. 


\section{Bibliography}

Bielecki T. (2018), Szczyt UE bez petnej zgody, co do migracji, “Gazeta Wyborcza” of October 19, 2018.

Buras P. (2018), Kryzys UE? Skadże!, "Gazeta Wyborcza” of November 12, 2018.

Cichocki M., Co z polskości mamy zabrać w przyszłość, "Rzeczpospolita” of September 15-16, 2018.

Jak straciliśmy złudzenia. Profesor uniwersytetu Harvarda Grzegorz Ekiert, socjolog i politolog o społecznej bazie dla populistycznej rebelii, Interview by Jacek Żakowski (2018), "Polityka", no. 38 .

Krzemiński A. (2018), W naszej części Europy znów jesteśmy w punkcie zwrotnym, “Dialog”, no. 123. Louven S. (2018), Staaten beschlißen Flüchtlingspaket, "Handelsblatt" of December 18, 2018.

Sakson A. (2016), Obraz Polski i Polaków w Niemczech, "Biuletyn Instytutu Zachodniego", no. 237.

“Serwis Instytutu Zachodniego" (2018), no. 61.

\section{Summary}

Among the many crises tormenting the Old Continent, the course and consequences of the migration crisis that began in 2015 are particularly noteworthy. There following issues should be highlighted:

- the migration crisis manifests the internal weakness of the EU, since it has not been predicted, effectively neutralized nor managed properly;

- the migration crisis has produced a division inside the EU;

- the migration crisis has led to internal political and social crises in many EU countries;

- the migration crisis has produced far-reaching outcomes (such as increased populism and xenophobia, division of Europe into the East and the West).

Key words: migration crisis, European Union, populism, xenophobia

\section{Uwagi o kryzysie migracyjnym jako wyzwaniu dla Unii Europejskiej w XXI wieku}

\section{Streszczenie}

Wśród wielu kryzysów trapiących Unię Europejską na szczególną uwagę zasługuje przebieg i konsekwencje kryzysu migracyjnego zapoczątkowanego w 2015 roku. Zwrócić należy uwagę na takie kwestie jak:

- kryzys migracyjny jest wyrazem wewnętrznej słabości UE, gdyż go nie przewidziano, skutecznie zneutralizowano i odpowiednio zarządzono;

- kryzys migracyjny skutkuje podziałem wewnątrz UE;

- doprowadził do wewnętrznych kryzysów polityczno-społecznych w wielu państwach UE;

- zaowocował dalekosiężnymi skutkami (m.in. wzrost populizmu i ksenofobii, podziały na linii Wschód-Zachód Europy).

Słowa kluczowe: kryzys migracyjny, Unia Europejska, populizm, ksenofobia 